SHS Web of Conferences 10, 00005 (2014)

DOI: $10.1051 /$ shsconf $/ 20141000005$

C Owned by the authors, published by EDP Sciences, 2014

\title{
The development of the concept of securities in Latvian legislation
}

\author{
M. Cernostana \\ Rīga Stradinsš University, Latvia
}

\begin{abstract}
The doctrinal analysis and legal regulation of the legal nature of the securities in Latvian law is fragmented and unclear. This paper discovers that according to the prevailing legal doctrine the securities are classified as intangibles under Latvian law and that leads to the exclusion of the dematerialized securities from the context of the property law. In contrast the bearer debt securities due to their dual legal nature get the legal treatment associated with the tangible movables, including the right to raise property claim and the protection of the bona fide acquirer, while other securities as intangibles do not have the benefit of these substantial property law rules, which leads to the significant legal uncertainty in case of the unauthorized transfer of the securities. The research takes the comparative approach, since historically Latvian securities law has experienced significant influence of the German law.
\end{abstract}

\section{Introduction}

Over the past few decades the concept of "securities" in Latvian legislation has developed from paperform securities to book-entry financial instruments. The securities in the Civil Law were meant as paper-form securities only, as securities in electronic (also known as book-entry) form has not been known at a time the Civil Law was drafted. But since 1937 the situation has change significantly. In the modern electronic securities holding system operated by the central securities depository and financial intermediaries the investors do not directly hold the bearer instruments in paper form and are not directly recorded as the owners of the securities in the registers of the issuers. The rights of the investors are recorded by the financial intermediaries, the records on the account of the investor held with intermediary represents the evidence of investor's right to the securities (Financial Instruments Market Law, Article 125 Part 2).

This practical development has not been followed by comprehensive doctrinal development. The doctrinal analysis and legal regulation of the legal nature of the securities in Latvian law is fragmented and unclear.

The scope and the nature of investors' rights to the securities represented by book-entry on the account held with the intermediary differ considerably in different jurisdictions not only worldwide, but also within the Europe. For instance the right of the investor represented by book-entry could be characterized as property rights to securities (French approach), bungle of rights against the intermediary (USA approach), co-ownership right of the investors in the same issue of securities held by the same

This is an Open Access article distributed under the terms of the Creative Commons Attribution License 4.0, which permits unrestricted use, distribution, and reproduction in any medium, provided the original work is properly cited. 
intermediary (German approach), etc. There is also difference in the legal characterization of rights represented by account records on different levels of securities holding system: there is a distinction between the securities accounts serving for the holding of securities for the ultimate owner and accounts that serve for maintenance of the records evidencing rights of the intermediaries. The position of Latvian legal doctrine in that spectrum of investors' rights characterization is far from being clear.

This research will concentrate on the examination of the former and existing Latvian legal rules governing the concept of "securities" in paper and dematerialized or book-entry form. The purpose of the research is to find out how the legal nature of the securities is classified and how this classification has developed throughout years. The paper seeks to answer the question whether the existing legal classification of the rights associated with the securities holding is clear, comprehensive and promotes legal certainty in the securities circulation.

The research takes the comparative approach, since historically Latvian securities law has experienced significant influence of the German law.

\section{Rights to securities: Historic background and modern doctrine}

The securities regulation in Latvian law dates back to the times of the Baltic Provinces Local Civil Laws Compilation. The rules on debt bearer securities have passed from the Baltic Provinces Local Civil Laws Compilation to the Civil Law almost unchanged. If we compare Articles 3120-3130 of the Baltic Provinces Local Civil Laws Compilation to the Articles 1524-1532 of the Civil Law, we see that the wording of these articles is almost identical.

Baltic Provinces Local Civil Laws Compilation itself to big extent gets its origin from the German law. In the view of the close relation between Latvian Civil law and German law it is interesting to compare Latvian Civil Law rules governing securities to the German law and German legal doctrine.

Currently in Germany most transferable securities are issued in the form of bearer instruments and are considered by the modern German legal doctrine as tangible movables (Micheler, 2007; 145). But the legal qualification of the securities under German law has undergone significant change since the times when the securities have first appeared. It is considered that the securities have first appeared in Germany during Napoleonic wars in the late eighteenth century as debt instruments aimed to finance the war expenses of the state (Micheler, 2007; 149). At the time when securities emerged, they were considered to be intangibles (Micheler, 2007; 150), were classified by German law as a debt and securities transfer was analyzed in terms of assignment (Micheler, 2007; 153), despite the fact that at those times securities existed only in paper form.

Reflecting the economic reality of the time, where the bearer paper form debt securities were the most widely used securities instruments, both Prussian and Austrian law first codified the rules on bearer debt securities (Micheler, 2007; 151). This starting point of the securities regulation within the framework of civil law, which later has developed and expanded in German law, in Latvian Civil Law has survived till today without any change, since bearer debt securities is still the only type of the securities regulated by the Civil Law, and Civil Law rules on the bearer debt securities are identical to those of the Baltic Provinces Local Civil Laws Compilation.

Originally the German law classified securities as debt or obligation. The securities as debt and as intangibles were supposed to be transferred by way of assignment. That legal analysis is rooted in the debt nature of the first securities. But the law of assignment in application to the securities had significant shortcomings. It precluded the issue of the securities to the bearer. In case of the bearer debt securities the securities are issued to unidentified creditor and that did not comply with the principles of German and Austrian contract law and the law of the assignment of that time [Micheler, 156]. Another problem associated with securities being classified as debt or obligation was related to the necessity to protect bona fide purchaser of the securities against adverse claim. Such protection has been considered essential for securities circulation in the market. Although Prussian and Austrian laws adopted special 


\section{Int. Conf. SOCIETY. HEALTH. WELFARE.}

rules protecting the bona fide acquirer of the securities, other German states didn't have such rule (Micheler, 2007; 156, 157) and that significantly increased the risks associated with the transfer of securities.

To overcome these shortcomings that created problems for the circulation of securities, German and Austrian legal doctrine came up with the new theory whereby the securities are classified as tangible movables and nowadays in Germany and Austria the transfer of the securities is governed by the same rules as transfer of tangibles (Micheler, 2007; 165).

The above overview of the historic aspects of German securities law is aimed to illustrate the development of legal doctrine and regulation that moved from classifying securities as a mere claim and transfer of the securities as the assignment to classifying securities as tangible movables and transfer of securities as transfer of assets.

That doctrinal development of the German and Austrian securities laws described in the previous section has not been followed by the Latvian law. On the contrary, in Latvian law there could still be found the residuals of the German eighteenth century doctrine and regulation. According to the Article 1527 of the Civil Law the "claim based on the bearer paper is assigned by transferring this paper from hand to hand". So as in early German and Austrian securities law the transfer of bearer debt securities under the Civil Law rules still is seen primary as an assignment of the claim evidenced by respective bearer security document. Besides, the rules on bearer debt securities are included in the section of the Civil Law dedicated to the contracts. The Article 1527 rule resembles Article 1393 of the Austrian Civil Code (Allgemeines Burgerlishes Gesetzbuch), which states that 'debt notes that are issued to the bearer are assigned by means of delivery and, apart from physical possession, do not require any further evidence of the assignment' (Micheler, 2007; 154). Austrian Civil Code came into force in 1811, when modern theory on securities, which now prevails both in German and Austrian law, had not been established yet (it had appeared in mid-nineteenth century), therefore the terminology used in Austrian law dates back to the "assignment theory", which is now abandoned by Austrian law (Micheler, 2007; 154).

Before German Civil Code (Burgerliches Gesetzbuch, BGB) was adopted in 1900, the Prussian and Austrian laws already contained the provisions for the protection of bona fide acquirers of the securities, which was the only exclusion from the general position of both legal systems which did not recognized the protection of bona fide acquirer in case of the assignment of the debt.

The same principle of bona fide bearer debt securities purchaser protection could be found in Latvian law. Both Baltic Provinces Local Civil Laws Compilation and Civil Law follows the tradition of Prussian and Austrian laws of late nineteenth century, and, although the transfer of bearer debt securities is analyzed in terms of the assignment in both legal acts, they contain special rules on the right to rise a claim to property and on the protection for bona fide acquirers of the debt securities certificates (Baltic Provinces Local Civil Laws Compilation, Article 3129; Civil Law, Article 1531). As it was explained above, from this starting point German and Austrian laws have moved forward and totally abandoned the "debt" and "assignment" elements of securities legal theory, eliminating the differences in legal treatment of securities and movable tangibles.

In contrast, in Latvian law nothing indicates that the original legal doctrine underlying the provisions of Articles 3120-2130 of the Baltic Provinces Local Civil Laws Compilation and Articles 1524-1532 of the Civil Law has got some new understanding or development.

In his comments to the Baltic Provinces Local Civil Laws Compilation the prominent scholar of the early twentieth century Bukovsky has analyzed the legal nature of the bearer debt securities:

The claim for property in relation to the bearer paper is explained by the fact that such paper is tangible, and the property right to it is divided from the possession. In case of such papers two elements should be considered:

1. The obligation, which is about the legal relations between the issuer of the bearer paper and its holder and where therefore the most important is the law of obligations; and 


\section{SHS Web of Conferences}

2. Right in rem, where the focus is on the paper itself and the right of ownership to the paper and where the question is in the relations between the former and the later holders of such a paper (Буковский, 1914; 1222).

Bukovsky has also considered the "assignment" element of the treatment of the bearer debt securities, which still could have been found in the law, and concluded, that:

The freedom and ease of the bearer paper circulation would suffer if the transfer of the right to claim should be done by way of assignment and each acquirer of the bearer paper needed to check, whether the transferor holds the paper rightly and legally. The freedom and ease of the bearer paper circulation therefore requires it to be transferred from hand to hand by mere transfer as a thing, but not in the form of the assignment. That today is firmly established in the theory and in the legal acts and the transfer of the right to claim under the bearer papers is discussed according to the rules on the acquisition of the property rights to the movable things (Буковский, 1914; 1213).

The dual nature of the paper form securities is discussed also in modern legal writing and there is the opinion that Civil Law rules on bearer debt securities should be interpreted widely and applied also to paper form equity instruments. Dematerialized securities are considered to be outside the Civil Law regulation in question (Tihonovs, 2012).

The opinion that securities which do not exist in paper form are intangibles has become an established legal doctrine (Pētījums par Civillikuma lietu tiesību daļas pirmās, otrās un trešās daļas modernizācijas nepieciešamību; 21). But apart from the conclusion that shares are intangibles and transfer of shares is performed by way of the contract (Lošmanis, 2011), the legal nature of securities and the consequences of such securities legal classification are not much discussed.

Meanwhile, if we qualify dematerialized securities as intangibles, but paper form securities as "dual nature" instruments that include the rights of obligation and the rights in rem but which circulation is governed mainly by the rules applicable to tangible movables, we will come to the result where economically identical rights would not receive identical protection, and the legal treatment of these rights will depend on the form in which these rights are certificated. Thus the right to rise property claim in case of unauthorized transfer of securities and special protection of bona fide acquirer granted by the Civil Law to bearer debt securities holders will be applied to paper form bearer debt securities and, possibly, to paper form shares (although the potential applicability of these rules to paper form shares is subject to further review and interpretation), but will not extend to the debt securities and shares existing in dematerialized form.

The dematerialized securities as intangibles will receive different legal treatment; such securities will not even be treated as the object of ownership within the traditional understanding of the Civil Law:

“... the law, judicial practice, and academic jurisprudence lean toward considering only tangible things as the object of ownership. This view is based on a single reference in the law, the limitation in Article 1050 of the CL, which prescribes that a claim for property can only be raised to recover a tangible thing..." (Rozenfelds, 2007, 26).

Intangibles are not subject to the general property law rules on the protection of property rights and protection of bona fide acquirer, but such protection is a necessary element of the bearer securities circulation. In the bearer securities transaction due to the form of the securities and the mode of securities transfer it is almost impossible to trace the origin of the securities and to determine, whether the transferor has acquired the securities legally or illegally. The same conclusion is true in relation to the dematerialized securities. In such a situation the absence of special legal rules protecting the bona fide acquirer the risk of the adverse claim would arise in each new transfer of the securities and that would be detrimental to the circulation of the securities.

The purpose of inclusion in bearer debt securities regulation of the Civil Law the rules providing the right to rise property claim and the protection of bona fide acquirer was to overcome the problems created by the classification of the bearer debt securities as intangibles. The problems that were acknowledged and resolved already in nineteenth century by the German and Austrian laws are not 


\section{Int. Conf. SOCIETY. HEALTH. WELFARE.}

acknowledged and are not resolved in modern Latvian law. Except for the Civil Law regulation on bearer debt securities that, most probably, gets its origin in the same German law rules of the nineteenth century, there are no clear and transparent rules on the protection of rights derived from the holding of the dematerialized securities, including the protection of the bona fide acquirer. The scope of mentioned Civil Law rules is limited to bearer debt securities. Applicability of these rules to the shares in paper form is questionable. Securities in dematerialized form as intangibles do not fit into the regulation of bearer debt securities in 1524-1532 of the Civil Law, since the applicability of the property law principles to the debt securities was justified by the tangible, movable nature of the bearer (paper) securities instrument.

There are attempts to qualify legal rights associated with the holding of the securities with the help of the concept of the possession of rights (Tihonovs, 2012), which in Latvia civil law is known as an actual power over the thing. The protection of rights associated with securities is proposed to achieve by applying Civil Law rules on the protection of possession (Tihonovs, 2012). But there is no specific procedural regulation of claims for the protection of possession, there is no respective case law in relation to securities. The law protects every possession, whether is legal or illegal, acquired in good faith or in bad faith (Civil Law Articles 911, 912), if the possession is taken away by force, it should be restored (Civil Law Article 921). The possible applicability of these rules to the disputes arising out of the unauthorized transfer of securities is far from clear. The law contains the concept of goodfaith possession, but there is no clear rule granting protection to the good faith possessor, therefore, if we analyze the transfer of securities in terms of possession, we still end up with the result that the risk of the adverse claim passes with each transfer of possession. The institute of possession in Latvian Civil law is controversial and is seen either as an independent legal institute or as an attribute of the property law (Rozenfelds, 2007; 21-23), therefore it does not add much to the legal transparency and predictability of the securities circulation. On the contrary, attributing to the bearer debt securities the rules applicable to the transfer of movable tangibles, and to the dematerialized securities the rules on the possession will lead to the different legal treatment of the economically identical property objects (the term "property" here is used in broad sense).

\section{Conclusions}

It is not difficult to agree with the words of professor Rozenfelds that "the narrow understanding of property rights inevitably leads to a narrow understanding of the subjective rights of individual owners" (Rozenfelds, 2007; 27). The classification of dematerialized securities as intangibles according to the prevailing legal doctrine leads to the exclusion of the dematerialized securities from the context of the property law. The result of such interpretation is the difference in legal treatment of the rights to the bearer debt securities (regulated by the Civil Law) and other securities. The bearer debt securities due to their dual nature get the legal treatment associated with the tangible movables, including the right to raise property claim and the protection of the bona fide acquirer, while other securities do not have the benefit of these substantial property law rules. Therefore the answer to the question of this research, whether the existing legal classification of the rights associated with the securities holding is clear, comprehensive and promotes legal certainty in the securities circulation, should be negative.

In case of the bearer securities already in nineteenth century the legal doctrine felt the necessity to fit these instruments into the construct of traditional property law. It is surprisingly that nowadays legal doctrine mainly overlooks the drawbacks of the approach, where some types of the securities are kept outside that property law construct. The fact that the bearer debt securities existed in paper form has facilitated for the legal doctrine the treatment of these securities as the object of the property. The only difference is that in this electronic century the rights to the securities held with intermediaries are evidenced not by paper, but by electronic means. Unfortunately the right to "the record" on the securities account does not fall within the concept of the "object of the property", which leads to the significant uncertainty regarding the protection of the holders of such securities in case of their 


\section{SHS Web of Conferences}

unauthorized transfer. Such uncertainty could be eliminated by applying the method used by the legal scholars of the past. The electronic record on the securities account evidencing the right to the security should be classified by the law as an object of the property and be given a special protection in case of the unauthorized transfer, including the right to raise a claim for property and the protection of the bona fide acquirer.

\section{References}

[1] Civillikums, "VV", 41, 20.02.1937.

[2] Finanšu instrumentu tirgus likums, 20.11.2003. "Latvijas Vēstnesis", 175 (2940), 11.12.2003.

[3] Lošmanis A., Tiesību jaunrāde šoreiz ir lieka, Jurista Vārds, 22.11.2011., 47 (694), http://www.juristavards.lv/index.php?menu=auth\&id=239727.

[4] Micheler, E., Property in Securities, A Comparatice Study, 19, Cambrige University Press, 2007.

[5] Rozenfelds, J., The Concept and Content of Property Rights, Latvijas Universitātes raksti, Juridiskā zinātne, 719. sēj., 2007., 19.-36. 1pp.

[6] Tihonovs, V., Ieskats akciju piederības jautājumā, Jurista Vārds, 22.05.2012., 21 (720), http://www.juristavards.lv/index.php?menu=auth\&id=247922.

[7] Pētījums par Civillikuma lietu tiesību daļas pirmās, otrās un trešās daļas modernizācijas nepieciešamību, http://www.tm.gov.lv/lv/ministrija/imateriali/petijumi.html.

[8] Буковский В. (Сост.) Сводь гражданскихь узаконений губерний Прибалтийскихь (сь продолжениемь 1912-1914 г. г. и сь разьяснениями) [Baltic Provinces Local Civil Laws Compilation (with continuation years 1912-1914 and with explanations)]. Т.2. Рига: Г. Гемпель и Ко, 1914. 